ISSN 2073-4441

www.mdpi.com/journal/water

Article

\title{
Science to Support Management of Receiving Waters in an Event-Driven Ecosystem: From Land to River to Sea
}

\author{
Catherine Leigh ${ }^{1,}{ }_{\dagger},{ }^{*}$, Michele A. Burford ${ }^{1}, \operatorname{Rod}$ M. Connolly ${ }^{2}$, Jon M. Olley ${ }^{1}$, Emily Saeck ${ }^{1}$, \\ Fran Sheldon ${ }^{1}$, James C.R. Smart ${ }^{1}$ and Stuart E. Bunn ${ }^{1}$
}

1 Australian Rivers Institute, Griffith University, 170 Kessels Road, Nathan, Queensland 4111, Australia; E-Mails: m.burford@griffith.edu.au (M.A.B.); j.olley@griffith.edu.au (J.M.O.); e.saeck@griffith.edu.au (E.S.); f.sheldon@griffith.edu.au (F.S.); j.smart@griffith.edu.au (J.C.R.S.); s.bunn@griffith.edu.au (S.E.B.)

2 Australian Rivers Institute, Griffith University, Gold Coast, Queensland 4222, Australia; E-Mail: r.connolly@griffith.edu.au

$\dagger$ Present address: Irstea, UR MALY, Biologie des Ecosystèmes Aquatiques, 5 rue de la doua, CS70077, 69626 Villeurbanne, France; E-Mail: catherine.leigh@irstea.fr.

* Author to whom correspondence should be addressed; E-Mail: c.leigh@griffith.edu.au; Tel.: +61-737-357-402; Fax: +61-737-357-615.

Received: 15 April 2013; in revised form: 27 May 2013 / Accepted: 6 June 2013 / Published: 19 June 2013

Abstract: Managing receiving-water quality, ecosystem health and ecosystem service
delivery is challenging in regions where extreme rainfall and runoff events occur
episodically, confounding and often intensifying land-degradation impacts. We synthesize
the approaches used in river, reservoir and coastal water management in the event-driven
subtropics of Australia, and the scientific research underpinning them. Land-use change
has placed the receiving waters of Moreton Bay, an internationally-significant coastal
wetland, at risk of ecological degradation through increased nutrient and sediment loads.
The event-driven climate exacerbates this issue, as the waterways and ultimately Moreton
Bay receive large inputs of nutrients and sediment during events, well above those received
throughout stable climatic periods. Research on the water quality and ecology of the
region's rivers and coastal waters has underpinned the development of a world-renowned
monitoring program and, in combination with catchment-source tracing methods and
modeling, has revealed the key mechanisms and management strategies by which
receiving-water quality, ecosystem health and ecosystem services can be maintained and 
improved. These approaches provide a useful framework for management of water bodies in other regions driven by episodic events, or where novel stressors are involved (e.g., climate change, urbanization), to support sustained ecosystem service delivery and restoration of aquatic ecosystems.

Keywords: ecosystem health; ecosystem services; adaptive management; flood; land use; erosion; restoration; riparian vegetation; water quality

\section{Ecological Management of Receiving Waters in Event-driven Ecosystems}

The management of receiving waters to optimize ecological and human-value objectives is a task undertaken collaboratively by scientists, economists, governments and communities in many regions across the world. Management programs differ according to their desired ecological and ecosystem service objectives, and because of differences in broad-scale factors, such as climate, geology and land use that drive spatial and temporal changes in the physical, chemical and biological characteristics of receiving waters. These factors play a determining role in the development of management programs and in the strategies required to meet management objectives.

Managing and restoring receiving-water quality, aquatic ecosystem health and ecosystem service delivery is challenging in regions where extreme rainfall and runoff events occur. During dry spells, large amounts of sediment and organic debris are stored in intermittently flowing channels, which are then released during high-power, highly erosive runoff events that can overwhelm sediment traps, swales and buffers. During these extreme events, large quantities of sediment, organic matter, nutrients and pollutants are mobilized from the land and upstream sources and transported via waterways downstream to adjacent wetlands and coastal waters within very short time periods. These events may occur infrequently or unpredictably, which can lead to uncertainty about the extent and frequency of monitoring required to encapsulate the full range of event characteristics and associated ecological responses. Further, their effects on receiving waters are often superimposed on seasonal or inter-annual changes in receiving-water quality and ecology, all of which require management consideration that is underpinned by detailed scientific understanding [1]. In addition, poor land use decisions are more likely to be made during long dry spells (e.g., encroachment of urban areas into floodplains), unpredictable flow events may occur when farmed floodplains are most vulnerable to erosion (e.g., when they have been recently plowed and seeded), and infrastructure such as levees and channelization that are implemented to deal with extreme flows can destabilize channels, leading to further problems during high flow events.

Australia is well known for its aridity but also for its water-regime variability [2], with event-driven systems found from coastal regions to internally-draining inland river systems [3]. The desire for a reliable supply of water for human use and flood mitigation has driven water infrastructure development over the last two centuries and resulted in the considerable modification of river flow regimes. Land cover and catchment hydrology has also changed dramatically during this period in comparison with the Northern Hemisphere, with extensive land clearing for pasture and agriculture associated with European settlement, and a rapid expansion of urban and industrial lands in recent 
decades. As a consequence, natural resource management must consider the impacts of current changes in land use together with considerable legacy issues, as well as the effects of and uncertainties associated with extreme climatic events [4]. This context has influenced the Australian development of approaches to ecological monitoring and management of receiving waters for event-driven ecosystems. We synthesize the scientific research that underpins the application of these approaches to river, reservoir and coastal water management in an event-driven region of subtropical Australia, and the research and modeling tools that are still required to underpin the restoration of these connected aquatic ecosystems and the ecosystem services they deliver. Our synthesis can be used to guide the ecological management of water bodies in other regions where land and water degradation are confounded by episodic climate events, or where novel stressors are involved (e.g., climate change, urbanization).

\section{South East Queensland, Australia}

South East Queensland (SEQ) is a subtropical region on Australia's east coast with a catchment area of $22,600 \mathrm{~km}^{2}$ and a peak elevation of $1360 \mathrm{~m}$ along its western edge [5,6]. The major river systems, the Albert, Brisbane, Caboolture, Logan and Pine Rivers, discharge into Moreton Bay, a coastal embayment of $\sim 1500 \mathrm{~km}^{2}$ protected under the Ramsar convention. The Queensland State capital city, Brisbane, has a population of $\sim 2$ million people, and the region as a whole has one of the fastest growing populations in Australia (currently 2.73 million people; 2026 projection $\sim 4$ million people).

Mean maximum monthly temperatures for SEQ range between 21 and $29^{\circ} \mathrm{C}$. The majority of the total annual rainfall $(900-1800 \mathrm{~mm}$ ) falls in the austral summer between the months of October and February. Strong seasonal variability in stream flow occurs as a result. However, there is also large inter-annual variability in both rainfall and stream flow [5,7] (Figure 1). Longer-term alternation between wet and dry periods also occurs; extended dry periods last on average 15 years, and wet periods 6 years [7]. Many of the streams in this region are defined as "unpredictable intermittent" [8].

Figure 1. Normalized cumulative deviations from the long-term mean annual rainfall for South East Queensland (SEQ) between 1870 and 2009, and average discharge across three river gauging stations with long-term data: Wide Bay Creek (1910-2005), Munna Creek (1928-2005) and Albert River (1910-2005) (modified from [7]). Vertical shaded bands show extended wet periods of above average rainfall and stream flow.

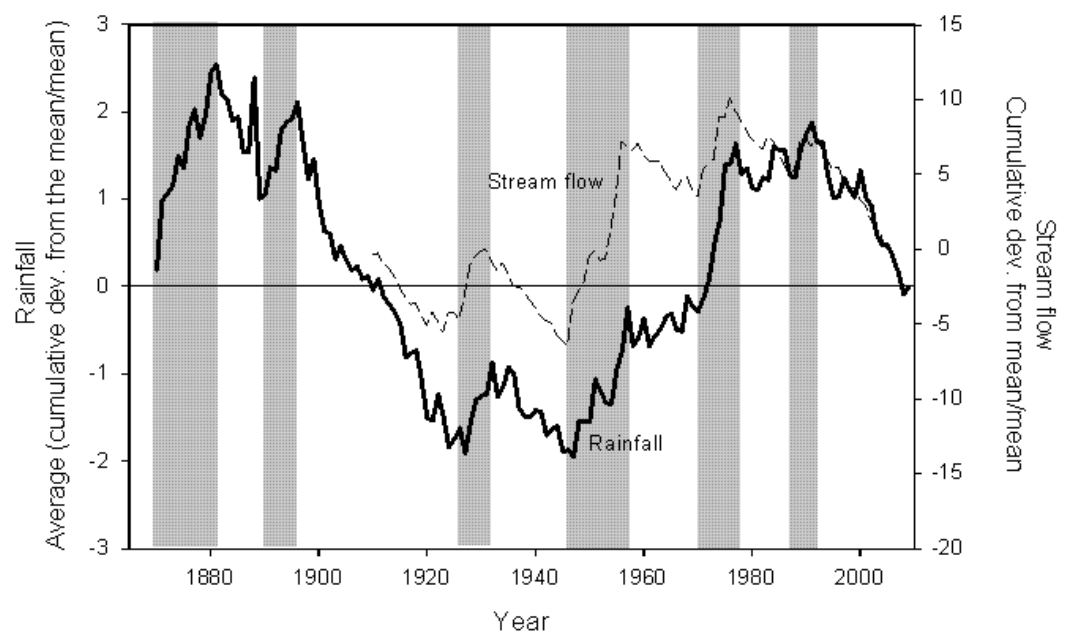


Before European settlement in 1823, there was extensive coverage of woody vegetation across the region's waterways and catchments [9], after which clearing began for cropping, grazing of domestic animals, and urban settlement. Timber from riparian zones was also cleared for export [10]. Since 1823, approximately two thirds of the native vegetation has been cleared, and more than half of the $48,000 \mathrm{~km}$ of streams in the region have riparian zones in poor condition. Current land uses include bushland (37\%), grazing (35\%), developed lands ( 7\%), managed forest and plantations ( 9\%) and agriculture $(\sim 6 \%)$.

The legacy of rapid land-use change and associated hydrological change in the region's streams and rivers has placed the receiving waters of Moreton Bay at risk of significant ecological degradation and decline in conservation value through increased nutrient and sediment loads [11]. The event-driven nature of the region's climate exacerbates this issue, as the waterways and ultimately Moreton Bay receive large, pulsed inputs of nutrients and sediment during flood events, which occur on top of the background-level inputs received during more-stable climatic periods.

\section{Receiving-Water Management Approaches: Rivers, Reservoirs and Coastal Waters}

\subsection{Water Quality and the Ecology of Rivers}

Changes in land cover and land-use intensification have long been associated with reduced ecosystem health in rivers as measured by a range of indicators [12,13]. Catchment and riparian forest cover offer protection to rivers by trapping sediments and nutrients and stabilizing stream channels, slowing flow velocities and increasing the extent of floodplain inundation, moderating water temperatures and therefore water quality through shading, and providing habitat for terrestrial life stages and organic matter as in-stream habitat [14]. This role may be even more important in event-driven systems where high rainfall and runoff generate high stream power and strong erosive forces on the channel network. Intact riparian vegetation can significantly reduce the export of this material from the terrestrial to aquatic environment $[15,16]$. Retaining these sediment and nutrient resources also enhances the ability of catchments to deliver valuable ecosystem services by, for example, supporting agricultural production with reduced requirement for artificial fertilizer inputs [17].

Land-use change, and in particular the reduction in catchment and riparian forest cover, was identified in the 1990s as the major driver of declining water quality and ecosystem health in SEQ streams and rivers [18]. In recognition of the threat that unchecked land-use change was likely to pose to the receiving waters of Moreton Bay, a monitoring program was established in SEQ in 2000 through cooperation between State government, local government, research organizations and local stakeholders [18]. The program (Ecosystem Health Monitoring Program, or EHMP) was designed specifically to detect and quantify the impacts of land-use change on river health using ecosystem response indices that show sensitivity to land-use change in catchments and riparian zones [18]. The freshwater component of the EHMP uses 14 indices, collected biannually from more than 130 sites across the region during the pre- and post-wet season periods. Indices are then grouped into water quality, ecosystem process, nutrient, macroinvertebrate and fish indicators to provide overall site scores of river health. 
An analysis of the first six years of freshwater EHMP data indicates that reduction in riparian cover in particular is associated with a reduction in river health, and is an important driver of declining water quality and freshwater diversity across the region [19]. Variation in river health due to natural versus anthropogenic effects was determined using mixed models that included variables describing variation in rainfall across sites during the sampling period, variables for seasonality, spatially-explicit land use variables, and a random component to capture natural variation among sites. Variation due to land use changes (e.g., loss of riparian forest cover) was therefore explicitly accounted for beyond that due to natural variation. The study found that $60 \%-80 \%$ upstream riparian cover of mid-dense forest would be required to maintain acceptable river health outcomes for the region (see also Section 4), including diverse communities of macroinvertebrate and native fish species [19]. Overall forest cover in the catchments was also found to have a significant effect on river health, as measured by the water quality and nutrient indicators. This research therefore suggests that a combination of near-stream and distributed forest cover in catchments will be required to maintain or improve river health in the region and to mitigate the impacts associated with episodic events that, due to catchment degradation, disturb receiving water quality and adversely affect aquatic fauna and the delivery of aquatic ecosystem services.

\subsection{Water Quality and the Ecology of Reservoirs}

Several river systems have been dammed in SEQ for flood control and/or water supply purposes, with the resultant reservoirs supplying the bulk of region's potable water supply and freshwater recreational zones. Ensuring water quality meets required guidelines (e.g., the Australian Drinking Water Guidelines) [20] and that potable water - a valuable provisioning ecosystem service - can be supplied in the required volume at modest cost, are therefore major concerns in reservoir management. Cyanobacterial phytoplankton blooms, including toxic species, taste and odor problems, aquatic weed growth and invasion of pest fish are key issues for many of the region's reservoirs. Further, the reservoirs receive high sediment and nutrient loads from catchments during episodic, high-magnitude inflow events [21], which can, at times, disrupt water treatment processes and impose significant additional costs on potable water supply.

Research has identified the mechanisms by which water quality issues are exacerbated in the reservoirs. Several studies have linked catchment land use (e.g., the proportion of land used for cattle grazing) and reservoir features (e.g., size and age) to reservoir water quality (e.g., [22,23]). For example, trajectories of increasing phytoplankton biomass (chlorophyll $a$ concentration) and abundance have been observed over time [24]. Research has also shown that while phytoplankton growth in the reservoirs is limited by both nitrogen and phosphorus [25,26], phosphorus additions can lead to preferential growth enhancement of Cylindrospermopsis raciborskii, a dominant toxic cyanobacteria in the reservoirs [27]. Together, these findings suggest that water quality is likely to continue to deteriorate if nutrient loads from catchments are not mitigated, and that effective management will require mitigation measures that target both nitrogen and phosphorus.

Research has therefore focused on identifying the specific catchment sources of nutrient inputs to the reservoirs to support targeted mitigation strategies (see also Section 4). Sources, forms and transformation of phosphorus, for example, have been identified in the catchment of Wivenhoe reservoir, the major source of drinking water in SEQ. Contrary to common belief, much of the 
phosphorus running off the catchment is in the dissolved inorganic form or loosely bound to soils owing to release from soil during wetting events [28-30]. As a result, the phosphorus can directly stimulate phytoplankton blooms, although the spatial and temporal scales over which this occurs depends on the turbidity of inflowing waters (which alters light availability) and the size, timing and source of those waters [19].

The water management authority in the region has recognized both the need for whole-of-catchment approaches to water quality remediation and the value of monitoring and research activities for informing these approaches and assessing their success [31]. A tool to assess overall condition of water storages and their catchments has been developed in a similar fashion to the EHMP, which is used to assess river health in SEQ (see above). The tool incorporates 16 indicators across five groups: best catchment management practices; catchment land use and sediment mobility; river riparian condition; and reservoir condition (Table 1), with this latter group represented by 17 water quality indicators that are scored against set guidelines. The development of such tools plays an important role in the ongoing assessment of catchment and reservoir management strategies to improve water quality, reduce water treatment costs and enhance delivery of other valuable ecosystem services such as water-related recreation. Clear, appropriate monitoring tools of this nature enhance the ability of management strategies to buffer the reservoirs against adverse water quality and ecosystem service impacts associated with rapid changes in inflow volume [31].

Table 1. Components of the condition assessment tool used to assess reservoir condition in SEQ [31].

\begin{tabular}{ll}
\hline Group & Indicator \\
\hline & \% grazing properties with property management plans \\
\%est management & \% grazing properties with $>90 \%$ median long-term groundcover \\
practice adoption & $\%$ agricultural properties on $<30 \%$ slope \\
& \% sewered urban properties \\
\hline & \% catchment within lowest 90th percentile for likelihood of \\
& containing pollutants \\
Catchment land-use and & \% catchment vegetated \\
sediment mobility & \% catchment within lowest 90th percentile for Universal Soil Loss \\
& Equation erosion hazard \\
\hline \multirow{2}{*}{ Riparian condition } & \% riparian area with vegetated cover \\
& $\%$ of stream length within vegetated cover \\
\hline & Good catchment condition with any land use appropriately managed \\
& Minimal cyanobacterial blooms \\
& Minimal incidence of bacteria and pathogens \\
& Low suspended sediment and nutrient levels \\
Reservoir condition & Suitability for primary human contact \\
& Healthy ecological condition \\
\hline
\end{tabular}




\subsection{Water Quality and the Ecology of Coastal Waters}

\subsubsection{Nutrient Loads and Phytoplankton Responses}

Eutrophication of coastal zones around the world has been associated with longer phytoplankton bloom seasons, shifts in phytoplankton community composition, higher frequency of harmful algal blooms events (HABs) and an increasing number of hypoxic dead zones [32-34]. In the late 20th Century, the nearshore areas of middle Moreton Bay were showing some symptoms of eutrophication, with elevated nutrient concentrations and phytoplankton abundance being recorded (Queensland Department of Environment and Resource Management, unpublished data). There were also several reports of blooms of a non-toxic dinoflagellate Cochlodinium helix, and other blooms which resulted in fish kills and localized anoxia [35].

In the 1990s, research into the nutrient and phytoplankton dynamics in Moreton Bay identified elevated nitrogen levels as the primary driver of the observed eutrophication symptoms. As a result, a series of investments were made in the early 2000 s to improve the nitrogen removal capacity of sewage treatment plants (STP) discharging into the embayment, including reducing the nitrogen loads from the region's major STP (Luggage Point) by approximately 70\% [36]. The focus on nitrogen was recommended based on results from a coupled physical and biogeochemical model of Moreton Bay [11,35] and on phytoplankton bioassay experiments that found that phytoplankton productivity responded primarily to nitrogen additions [37,38]. Lower sewage nitrogen signals in the bay $[39,40]$ and declines in annual mean phytoplankton biomass (chlorophyll $a$ concentration) [36,41] suggested that the investments were effective in reducing the symptoms of eutrophication that had prevailed in earlier decades.

Identifying causality between reduced STP loads and desired changes in the phytoplankton community proved challenging, however, because of a shift in rainfall pattern across SEQ from a wet to dry phase that was coincident with the period of improvement. In event-driven systems, a single high-rainfall event can deliver more nutrients than the annual average sewage nutrient load. Therefore, the shift to a dry phase, with the resultant reduction in frequency and magnitude of rainfall events and land-derived nutrient loads to the bay, may have instigated significant changes in the resident phytoplankton communities. Recognizing this, Saeck et al. [41] analyzed a combination of long-term water-quality-monitoring data from the bay (the estuarine/marine component of EHMP) and freshwater flow data from a bay-specific hydrodynamic model [42] to untangle the confounding effects of rainfall and runoff variation on nitrogen loads from the effect of the STP upgrades (Figure 2). Results confirmed that declines in phytoplankton biomass in the middle and nearshore areas of the bay were associated with the decline in chronic STP nitrogen loads.

However, the considerable role that extreme and episodic flow events play in delivering nutrients that stimulate phytoplankton growth in the bay [43] indicates that effective mitigation strategies will require a combination of chronic point source (STP) and diffuse catchment source management [41] (see also Section 4). Policy mechanisms such as nutrient or sediment trading schemes which encourage mitigation of emissions from point and diffuse sources in combination could-dependent upon prevailing catchment conditions - provide enhanced opportunities for improving the cost-effectiveness of catchment scale mitigation. These studies also highlight the use of targeted field research and the 
benefits of maintaining long-term monitoring programs for the assessment of management strategies designed to improve ecosystem health in receiving waters.

Figure 2. Brisbane River nitrogen loads $\left(\mathrm{t}^{-1}\right)$ from the major sewage treatment plants (STP) (Luggage Point) in the region, and from diffuse loads, discharged at the mouth into Moreton Bay (modified from [41]).

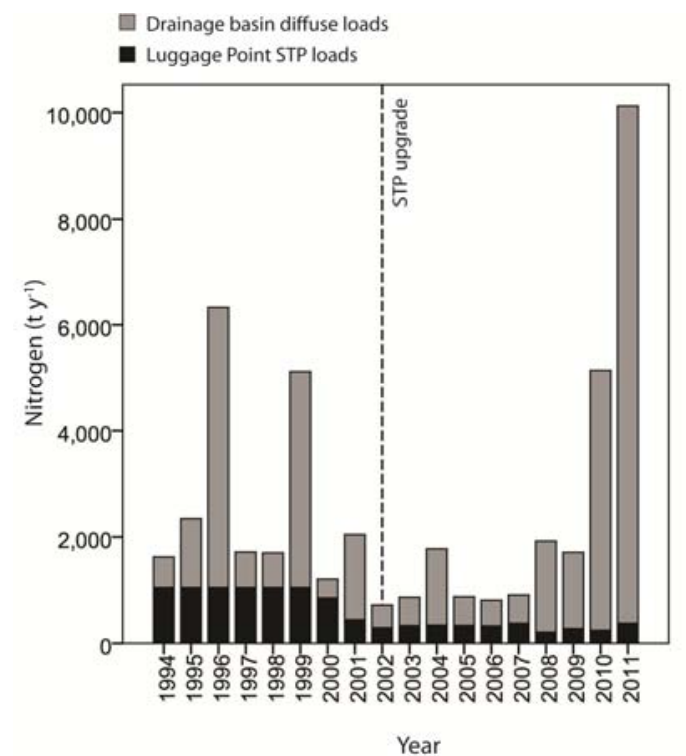

\subsubsection{Seagrass, Turtles and Dugongs}

As is typical of protected coastal embayments in Australia, seagrass meadows are a conspicuous component of the ecosystem of Moreton Bay. Initial studies highlighted their importance in the bay through provision of structure for prawn and fish communities, themselves the basis for valuable recreational and commercial fisheries [44], and as food for green turtles (Chelonia mydas) and herds of dugongs (Dugong dugon) [45,46]. Recent revelations about the high rates of carbon sequestration in sediment within seagrass meadows only serve to further their importance, emphasizing the valuable ecosystem services that these habitats support and deliver [47].

The distribution of seagrass in Moreton Bay has been altered greatly over the last 50 years, with substantial loss and fragmentation of meadows subsequent to massive, episodic riverine inputs and concomitant poor water quality [48]. Declining abundances of green turtles and dugongs, charismatic megafauna reliant on seagrass, have also been recorded. Large meadows are now restricted to the eastern bay, where they are considered nutrient limited [49]. Meadows in the western bay adjacent to the metropolitan area of Brisbane have suffered from highly turbid, nutrient rich waters and now cover only a fraction of their former distribution [48].

The key role of seagrass and conspicuous change in its distribution led to its use as a sentinel indicator of ecosystem health [50]. The light requirements for seagrass growth are central to the setting of turbidity levels in water quality guidelines [51] and provide a firm target that underpins modeling of required catchment restoration [6]. Alongside the work of catchment restoration aimed at improving water quality in the bay (see Section 4), scientific studies are examining other aspects of seagrass resilience 
such as the relationship with the nuisance algae, Caulerpa taxifolia [52], and factors inhibiting natural seagrass regeneration in denuded areas.

Although a gradient in water quality existed historically across the bay, from more riverine conditions in the west to more oceanic in the east, this difference has been greatly amplified following changes in flow, sediment and nutrient loads driven by wholesale land-use changes in the bay's catchments [53]. In addition to the obvious need for improving water quality through catchment restoration, management actions that restrict certain human activities in highly managed sections of the bay are also proving useful. Boating go-slow zones have been implemented to limit boat strikes on turtles and dugongs, and restrictions on fishing have resulted in higher densities of grazing fish, which most likely promote seagrass growth by reducing epiphytic algae, and have also benefitted other habitats such as coral reefs [54].

\section{Restoration Approaches: Addressing Ecosystem Health Decline from Land to River to Sea}

Decline in Moreton Bay's ecosystem health and likely concomitant declines in ecosystem service delivery have been indicated by increasing frequency of phytoplankton blooms, disappearance of seagrass beds, and declining water quality [51,55]. This decline in ecosystem services has been attributed primarily to increased sediment and nutrient inputs from catchment sources [5,6], with current sediment loads to the bay estimated to be 30 times the pre-European settlement rates [56] as a result of stream incision and gully erosion associated with extensive clearing in catchment uplands and riparian zones, and other land-use change (e.g., floodplain cultivation, over-grazing and urban development) [7,57-59]. To address the decline in Moreton Bay's ecosystem health, the regional management plan has set the target of reducing sediment loads by $50 \%$.

Studies using fallout radionuclide concentrations to determine whether sediment sources are derived from surface soil or channel sources have shown that channel (gully and bank) erosion dominates source supply in the SEQ region [60-62]. Clearing of vegetation from hillslopes in the early 20th century would have produced a substantial increase in runoff as a result of decreased evapo-transpiration and decreased interception. Using the relationship of Zhang et al. [63], we estimate that this change would have more than doubled the runoff from cleared areas. Removal of in-channel and riparian vegetation would have further decreased the ability of the channels themselves to resist erosion. These studies collectively suggest that, to be effective, conservation efforts to reduce sediment supply should focus on reforestation of gully and channel networks and on decreasing runoff to channel networks [62].

However, more than half of the region's $48,000 \mathrm{~km}$ of channel network is considered to be in poor ecological condition, and rehabilitation of this entire network would be a daunting and financially prohibitive task. This has led to the determination of the effect of remnant riparian vegetation on sediment and nutrient loads delivered to waterways in the region [16]. Using event-based water quality data, Olley et al. found that the sediment yield per unit area from cleared catchments is between 50 and 200 times that of fully vegetated catchments, with a best estimate of 100 times [16]. For total phosphorus it is between 25 and 60 times, with a best estimate of 40 times, and for total nitrogen between 1.6 and 4.1 times. Using these results, it has been estimated that reducing sediment and phosphorus loads to Moreton Bay by $50 \%$ would involve rehabilitating $6000 \mathrm{~km}$ of the 24,000 km of 
degraded channel network to the same condition as the remnant woodland areas (assuming that this is possible) [16]. This is probably an over estimate of the proportion of the channel that will require rehabilitation, however, because it is based on the assumption that the poorly vegetated sections of the channel network contribute uniformly to the sediment load. The reality is that most of the sediments are derived from only a small proportion of the channel network. In the Knapp Creek catchment, a $75 \mathrm{~km}^{2}$ subcatchment, for example, $90 \%$ of the sediment comes from less than $20 \%$ of the catchment area [64].

Although riparian zone revegetation to control sediment erosion remains to be tested in the SEQ region, studies elsewhere indicate that sediment inputs to streams from bank erosion and channel instability can reduce quickly and dramatically in response to riparian restoration [65]. For SEQ, researchers have suggested that conservation efforts should first focus on protecting areas where the riparian cover is in relatively good condition [66] and then on revegetating the channel network in priority areas [16]. This will significantly alter the channel roughness, slowing the flows and increasing the extent of floodplain inundation [64], and such an approach is likely to result in the improved water quality and overall ecosystem health of the region's rivers and coastal waters, including the ecologically significant Moreton Bay. It is also likely to reduce the costs incurred in treating water for potable use.

\section{Future Directions and Challenges}

The management approaches recommended and used to mitigate impacts of land degradation on water quality, ecosystem health and ecosystem service delivery in SEQ have been underpinned by comprehensive scientific research and long-term monitoring programs (Table 2). These programs and the adaptive-management approach they embody [18] have been used to guide the development of science-based river health assessments throughout the world to identify the likely causes of decline in ecological condition and ecosystem service provision (e.g., in China) [67].

Table 2. Receiving-water management issues in SEQ and the mitigation strategies applied or recommended, as underpinned by research.

\begin{tabular}{|c|c|c|c|}
\hline $\begin{array}{l}\text { Receiving } \\
\text { water }\end{array}$ & $\begin{array}{l}\text { Receiving-water } \\
\text { management issue }\end{array}$ & Mitigation strategies & $\begin{array}{l}\text { Examples of science } \\
\text { underpinning the } \\
\text { approaches }\end{array}$ \\
\hline \multirow[t]{2}{*}{ Rivers } & Poor water quality & $\begin{array}{l}\text { Reducing loads of nutrients and } \\
\text { sediment from catchments; } \\
\text { Revegetating riparian zones and } \\
\text { catchments }\end{array}$ & {$[19,68]$} \\
\hline & $\begin{array}{l}\text { Macroinvertebrate and } \\
\text { native fish diversity decline }\end{array}$ & $\begin{array}{l}\text { Revegetating riparian zones } \\
\text { and catchments }\end{array}$ & [19] \\
\hline \multirow[t]{3}{*}{ Reservoirs } & $\begin{array}{l}\text { Blooms of toxic } \\
\text { cyanobacteria }\end{array}$ & $\begin{array}{l}\text { Reducing loads of nitrogen and } \\
\text { phosphorus from catchments }\end{array}$ & {$[25,26,69]$} \\
\hline & Taste and odour compounds & $\begin{array}{l}\text { Reducing loads of nitrogen and } \\
\text { phosphorus from catchments }\end{array}$ & [70] \\
\hline & Poor water quality & $\begin{array}{l}\text { Best land management practices; } \\
\text { Reducing loads of nutrients and } \\
\text { sediment from catchments }\end{array}$ & {$[21,23,31]$} \\
\hline
\end{tabular}


Table 2. Cont.

\begin{tabular}{llll}
\hline $\begin{array}{l}\text { Receiving } \\
\text { water }\end{array}$ & $\begin{array}{l}\text { Receiving-water } \\
\text { management issue }\end{array}$ & Mitigation strategies & $\begin{array}{l}\text { Examples of science } \\
\text { underpinning the } \\
\text { approaches }\end{array}$ \\
\hline Rivers & Poor water quality & $\begin{array}{l}\text { Reducing loads of nutrients and } \\
\text { sediment from catchments; } \\
\text { Revegetating riparian zones and } \\
\text { catchments }\end{array}$ & {$[19,68]$} \\
& Macroinvertebrate and & $\begin{array}{l}\text { Revegetating riparian zones } \\
\text { and catchments }\end{array}$ & {$[19]$} \\
\hline Reservoirs & $\begin{array}{l}\text { Beducing loads of nitrogen and } \\
\text { cyanobacteria }\end{array}$ & $\begin{array}{l}\text { phosphorus from catchments } \\
\text { Reducing loads of nitrogen and } \\
\text { phosphorus from catchments }\end{array}$ & {$[25,26,69]$} \\
& Taste and odour compounds & {$[70]$} \\
& & $\begin{array}{l}\text { Best land management practices; } \\
\text { Reducing loads of nutrients and } \\
\text { sediment from catchments }\end{array}$ & {$[21,23,31]$} \\
\hline
\end{tabular}

Some of the recommended mitigation measures for SEQ, however, still await full implementation. Additional research and modeling to quantify the optimal size, intensity and spatial arrangement of restoration that will produce the desired improvements in water quality, ecosystem health and ecosystem service delivery for the lowest total cost $[18,19]$ is still required, as is the commitment to invest in regional-scale implementation.

In regions with temperate climates, where episodic events occur much less frequently than in SEQ, catchment-scale models that are spatially-explicit and integrate environmental, ecological and economic components have been developed to identify the most cost-effective combination of mitigation measures to achieve desired reductions in pollutant loads to receiving waters [71,72]. This type of modeling, known as catchment-scale spatially-specific cost-effectiveness optimization, requires close integration of natural science models that predict (i) the effectiveness of mitigation measures at source; and (ii) sediment and nutrient transport between source locations and receiving waters; together with (iii) economic models that predict spatially-specific, intensity-specific costs for the different mitigation measures. These models recognize that implementing the same mitigation measure with the same intensity in two different locations will not necessarily deliver the same effective load reduction in receiving waters, nor necessarily incur the same incremental costs. The models also recognize that the same level of increase in implementation intensity from two different initial intensities (e.g., an intensity increase from $10 \%$ to $15 \%$ versus an increase from $25 \%$ to $30 \%$ ) will not necessarily deliver the same incremental effect on receiving pollutant loads, or incur the same incremental cost. Building on earlier integrated modeling work [73-78], integrated environmental-ecological-economic models could be produced that explicitly acknowledge the event-driven nature of SEQ's catchments when producing spatially-specific predictions of mitigation effectiveness and mitigation cost.

Optimization approaches can inform catchment management by identifying the most effective mitigation measures and, ideally, the intensity and location(s) at which these measures should be applied to achieve a desired set of pollutant load reductions and ecosystem health and ecosystem 
service outcomes at minimum cost. Cost-effectiveness optimization only seeks to identify the minimum cost combination of location-specific mitigation measures to achieve a particular set of load reduction targets in specified receiving waters; it does not typically account for any concomitant changes in the delivery of market and non-market ecosystem services in the catchment itself or in receiving waters. (The work by Hall [78], however, is an SEQ-relevant exception in including social benefits from greenhouse gas reductions and pollutant reductions alongside mitigation costs in undertaking an extended cost-effectiveness analysis of total water cycle management in one case study SEQ catchment.) Systematic rehabilitation planning offers a potential solution by combining an understanding of ecosystem processes together with estimates of the likely costs incurred by different socio-economic stakeholders within cost-effectiveness analyses for spatially-specific, catchment-scale rehabilitation planning and implementation [79].

Many of the ecosystem services that are affected by anthropogenic impacts in catchments deliver public rather than private benefits; in SEQ, for example, this includes services such as carbon sequestration in seagrass meadows. Quantifying the full scale of social net benefits that accrue from implementing mitigation measures strengthens the case for public funding of catchment management initiatives and for payments for ecosystem services approaches to incentivize beneficial changes in management practices on privately owned riparian land holdings [76,80,81]. Existing cost benefit analyses of improved catchment management in SEQ suggest that the social benefits obtained are likely to exceed the costs incurred [73,75,76]. However, to the authors' knowledge, none of the existing SEQ cost benefit analyses account explicitly for the event-driven nature of SEQ's catchment systems when quantifying the effectiveness of mitigation measures, the scale of benefits delivered and/or event-driven impacts on mitigation costs. Extending social cost benefit analysis to account explicitly for both short-term event-mediated flow peaks and longer-term wet/dry cycling would provide another relevant and timely step forward.

While the economic and environmental case for riparian and catchment rehabilitation in this region appears convincing [73,75,76,78], large-scale implementation remains elusive. Much of the on-ground investment to date has been poorly targeted and too small-scale to enable the resulting benefits to be quantified robustly against the backdrop of high climatic variability. Worse still, local actions by landowners in headwater streams, supported by Government, in response to recent floods are likely to increase stream power and channel erosion and further impact on water quality and environmental values downstream. Governments have been reluctant to commit to fund and oversee the regional-scale planning and implementation that is required to deliver these important and highly valuable environmental and social outcomes.

\section{Conclusions}

While the need for remedial action in the catchments and riparian zones to improve receiving-water quality in the region is clear, there is an equally important need to increase the recognition of the value of receiving-waters as functioning ecosystems that support biodiverse communities, and as providers of highly-valuable ecosystem services. Robust and defensible science and monitoring programs, and effective communication of key findings and their implications are essential elements for success. However, these alone cannot guarantee that desired management actions will be achieved. This also 
requires champions in government, as well as in the scientific and broader community, to provide leadership and a vision for change.

\section{Acknowledgments}

Research conducted by authors of this manuscript was supported by an Australian Postgraduate Award, an Australian Research Council Linkage Grant (LP0668369), CSIRO Water for a Healthy Country Flagship, South East Queensland Healthy Waterways Partnership, and Australian Rivers Institute. We thank Paul Maxwell for advice about seagrass resilience.

\section{Conflict of Interest}

The authors declare no conflict of interest.

\section{References}

1. Watson, I.; Burnside, D.; Holm, A. Event-driven or continuous; which is the better model for managers? Rangel. J. 1996, 18, 351-369.

2. Puckridge, J.T.; Sheldon, F.; Walker, K.F.; Boulton, A.J. Flow variability and the ecology of large rivers. Mar. Freshw. Res. 1998, 49, 55-72.

3. Finlayson, B.L.; McMahon, T.A. Australia v. the World: A Comparative Analysis of Streamflow Characteristics. In Fluvial Geomorphology of Australia; Warner, R.F., Ed.; Academic Press: Sydney, Australia, 1988; pp. 17-40.

4. Clark, M.J. Dealing with uncertainty: Adaptive approaches to sustainable river management. Aquat. Conserv. Mar. Freshw. Ecosyst. 2002, 12, 347-363.

5. Abal, E.G.; Bunn, S.E.; Dennison, W.C. Healthy Waterways, Healthy Catchments: Making the Connection in South East Queensland, Australia; Moreton Bay and Catchments Partnership: Brisbane, Australia, 2005; p. 222.

6. Bunn, S.E.; Abal, E.G.; Greenfield, P.F.; Tarte, D.M. Making the connection between healthy waterways and healthy catchments: South East Queensland, Australia. Water Sci. Technol. Water Supply 2007, 7, 93-100.

7. Saxton, N.E.; Olley, J.M.; Smith, S.; Ward, D.P.; Rose, C.W. Gully erosion in sub-tropical south-east Queensland, Australia. Geomorphology 2012, 173-174, 80-87.

8. Kennard, M.J.; Pusey, B.J.; Olden, J.D.; Mackay, S.J.; Stein, J.L.; Marsh, N. Classification of natural flow regimes in Australia to support environmental flow management. Freshw. Biol. 2010, 55, 171-193.

9. National Vegetation Information System (NVIS). Available online: http://www.environment.gov.au/ erin/nvis/mvg/index.html\#mvg (accessed on 1 December 2011).

10. Bolton, G.C. They Hated Trees. In Spoils and Spoilers: A History of Australians Shaping Their Environment; Curthoy, A., Ed.; Allen and Unwin: Sydney, Australia, 1992; pp. 37-48.

11. Dennison, W.; Abal, E. Moreton Bay Study: A Scientific Basis for the Healthy Waterways Campaign; South East Queensland Regional Water Quality Management Strategy: Brisbane, Australia, 1999; p. 246. 
12. Allan, J.D. Landscapes and riverscapes: The influence of land use on stream ecosystems. Annu. Rev. Ecol. Evol. Syst. 2004, 35, 257-284.

13. Weijters, M.J.; Janse, J.H.; Alkemade, R.; Verhoeven, J.T.A. Quantifying the effect of catchment land use and water nutrient concentrations on freshwater river and stream biodiversity. Aquat. Conserv. Mar. Freshw. Ecosyst. 2009, 19, 104-112.

14. Naiman, R.J.; Decamps, H. The ecology of interfaces: Riparian zones. Ann. Rev. Ecol. Syst. 1997, $28,621-658$.

15. Newham, M.; Fellows, C.; Sheldon, F. Functions of riparian forest in urban catchments: A case study from sub-tropical Brisbane, Australia. Urban Ecosyst. 2010, 14, 165-180.

16. Olley, J.; Burton, J.; Hermoso, V.; Smolders, K.; McMahon, J.; Thomson, B.; Watkinson, A. Remnant vegetation, sediment and nutrient loads, and river rehabilitation in subtropical Australia. Hydrol. Process. 2013, Submitted for publication.

17. Cordell, D.; Drangert, J.-O.; White, S. The story of phosphorus: Global food security and food for thought. Glob. Environ. Chang. 2009, 19, 292-305.

18. Bunn, S.E.; Abal, E.G.; Smith, M.J.; Choy, S.C.; Fellows, C.S.; Harch, B.D.; Kennard, M.J.; Sheldon, F. Integration of science and monitoring of river ecosystem health to guide investments in catchment protection and rehabilitation. Freshw. Biol. 2010, 55, 223-240.

19. Sheldon, F.; Peterson, E.E.; Boone, E.L.; Sippel, S.; Bunn, S.E.; Harch, B.D. Identifying the spatial scale of land use that most strongly influences overall river ecosystem health score. Ecol. Appl. 2012, 22, 2188-2203.

20. National Health and Medical Research Council (NHMRC); National Resource Management Ministerial Council (NRMMC). Australian Drinking Water Guidelines Paper 6: National Water Quality Management Strategy; Commonwealth of Australia: Canberra, Australia, 2011.

21. Burford, M.; Green, S.; Cook, A.; Johnson, S.; Kerr, J.; O’Brien, K. Sources and fate of nutrients in a subtropical reservoir. Aquat. Sci. 2012, 74, 179-190.

22. Burford, M.A.; Johnson, S.A.; Cook, A.J.; Packer, T.V.; Taylor, B.M.; Townsley, E.R. Correlations between watershed and reservoir characteristics, and algal blooms in subtropical reservoirs. Water Res. 2007, 41, 4105-4114.

23. Leigh, C.; Burford, M.A.; Roberts, D.T.; Udy, J.W. Predicting the vulnerability of reservoirs to poor water quality and cyanobacterial blooms. Water Res. 2010, 44, 4487-4496.

24. Antenucci, J.P.; Ghadouani, A.; Burford, M.A.; Romero, J.R. The long-term effect of artificial destratification on phytoplankton species composition in a subtropical reservoir. Freshw. Biol. 2005, 50, 1081-1093.

25. Muhid, P.; Burford, M.A. Assessing nutrient limitation in a subtropical reservoir. Inland Water. 2012, 2, 185-192.

26. Muhid, P.; Davis, T.W.; Bunn, S.E.; Burford, M.A. Effects of inorganic nutrients in recycled water on freshwater phytoplankton biomass and composition. Water Res. 2013, 47, 384-394.

27. Posselt, A.J.; Burford, M.A.; Shaw, G. Pulses of phosphate promote dominance of the toxic cyanophyte Cylindrospermopsis raciborskii in a subtropical water reservoir. J. Phycol. 2009, 45, 540-546.

28. Kerr, J.G.; Burford, M.; Olley, J.; Udy, J. The effects of drying on phosphorus sorption and speciation in subtropical river sediments. Mar. Freshw. Res. 2010, 61, 928-935. 
29. Kerr, J.G.; Burford, M.A.; Olley, J.M.; Bunn, S.E.; Udy, J. Examining the link between terrestrial and aquatic phosphorus speciation in a subtropical catchment: The role of selective erosion and transport of fine sediments during storm events. Water Res. 2011, 45, 3331-3340.

30. Kerr, J.G.; Burford, M.; Olley, J.; Udy, J. Phosphorus sorption in soils and sediments: Implications for phosphate supply to a subtropical river in southeast Queensland, Australia. Biogeochemistry 2011, 102, 73-85.

31. Watkinson, A.; Volders, A.; Smolders, K.; Simms, A.; Olley, J.; Burford, M.; Stratton, H.; Gibbes, B.; Grinham, A. Source water protection for Seqwater: Novel techniques to assess the effectiveness of management intervention and prioritise action. Water 2012, 39, 100-105.

32. Cloern, J.E. Our evolving conceptual model of the coastal eutrophication problem. Mar. Ecol. Prog. Ser. 2001, 210, 223-253.

33. Diaz, R.J.; Rosenberg, R. Spreading dead zones and consequences for marine ecosystems. Science 2008, 321, 926-929.

34. Rabalais, N.N.; Diaz, R.J.; Levin, L.A.; Turner, R.E.; Gilbert, D.; Zhang, J. Dynamics and distribution of natural and human-caused hypoxia. Biogeosciences 2010, 7, 585-619.

35. McEwan, J.; Gabric, A.J.; Bell, P.R.F. Water quality and phytoplankton dynamics in Moreton Bay, south-eastern Queensland. II. Mathematical modelling. Mar. Freshw. Res. 1998, 49, 227-239.

36. Wulff, F.; Eyre, B.D.; Johnstone, R. Nitrogen versus phosphorus limitation in a subtropical coastal embayment (Moreton Bay; Australia): Implications for management. Ecol. Model. 2011, 222, 120-130.

37. Glibert, P.; Heil, C.; O’Neil, J.; Dennison, W.; O’Donohue, M.H. Nitrogen, phosphorus, silica, and carbon in Moreton Bay, Queensland, Australia: Differential limitation of phytoplankton biomass and production. Estuar. Coast. 2006, 29, 209-221.

38. O’Donohue, M.H.; Dennison, W. Phytoplankton productivity response to nutrient concentrations, light availability and temperature along an Australian estuarine gradient. Estuaries 1997, 20, 521-533.

39. Costanzo, S.D.; Udy, J.; Longstaff, B.; Jones, A. Using nitrogen stable isotope ratios $\left(\delta^{15} \mathrm{~N}\right)$ of macroalgae to determine the effectiveness of sewage upgrades: Changes in the extent of sewage plumes over four years in Moreton Bay, Australia. Mar. Pollut. Bull. 2005, 51, 212-217.

40. Rissik, D.; Darnell, R. Estuaries and Moreton Bay, EHMP Trends in Ecosystem Health 2000-2009; Healthy Waterways: Brisbane, Australia, 2013; in press.

41. Saeck, E.A.; O’Brien, K.R.; Weber, T.R.; Burford, M.A. Changes to chronic nitrogen loading from sewage discharges modify standing stocks of coastal phytoplankton. Mar. Pollut. Bull. 2013, in press.

42. Weber, T.; Stewart, J. Benefits and Limitations of Current Approaches to Whole of Catchment Modelling. In Proceedings of the 18th World IMACS Congress and MODSIM09 International Congress on Modelling and Simulation, Cairns, Australia, 13-17 July 2009; Anderssen, R.S., Braddock, R.D., Newham, L.T.H., Eds.; Modelling and Simulation Society of Australia and New Zealand and International Association for Mathematics and Computers in Simulation: Canberra, Australia, 2009; pp. 4071-4077.

43. Saeck, E.; Hadwen, W.; Rissik, D.; O’Brien, K.; Burford, M. Flow events drive patterns of phytoplankton distribution along a river-estuary-bay continuum. Mar. Freshw. Res. 2013, in press. 
44. Tibbetts, I.R.; Connolly, R.M. The Nekton of Moreton Bay. In Moreton Bay and Catchment; Tibbetts, I.R., Hall, N.J., Dennison, W.C., Eds.; School of Marine Science, University of Queensland: Brisbane, Australia, 1998; pp. 395-420.

45. Lanyon, J.M. Distribution and abundance of dugongs in Moreton Bay, Queensland, Australia. Wildl. Res. 2003, 30, 397-409.

46. Arthur, K.E.; Boyle, M.C.; Limpus, C.J. Ontogenetic changes in diet and habitat use in green sea turtle (Chelonia mydas) life history. Mar. Ecol. Prog. Ser. 2008, 362, 303-311.

47. Fourqurean, J.W.; Duarte, C.M.; Kennedy, H.; Marbà, N.; Holmer, M.; Mateo, M.A.; Apostolaki, E.T.; Kendrick, G.A.; Krause-Jensen, D.; McGlathery, K.J.; et al. Seagrass ecosystems as a globally significant carbon stock. Nat. Geosci. 2012, 5, 505-509.

48. Roelfsema, C.M.; Phinn, S.R.; Udy, N.; Maxwell, P. An integrated field and remote sensing approach for mapping Seagrass Cover, Moreton Bay, Australia. J. Spat. Sci. 2009, 54, 45-62.

49. Udy, J.W.; Dennison, W.C. Growth and physiological responses of three seagrass species to elevated sediment nutrients in Moreton Bay, Australia. J. Exp. Mar. Biol. Ecol. 1997, 217, 253-277.

50. Abal, E.G.; Loneragan, N.; Bowen, P.; Perry, C.J.; Udy, J.W.; Dennison, W.C. Physiological and morphological responses of the seagrass Zostera capricorni Aschers, to light intensity. J. Exp. Mar. Biol. Ecol. 1994, 178, 113-129.

51. Abal, E.G.; Dennison, W.C. Seagrass depth range and water quality in southern Moreton Bay, Queensland, Australia. Mar. Freshw. Res. 1996, 47, 763-771.

52. Burfeind, D.D.; Udy, J.W. The effects of light and nutrients on Caulerpa taxifolia and growth. Aquat. Bot. 2009, 90, 105-109.

53. Bennett, J.; Fisk, G.; Abal, E.; Stevens, T.; Connolly, R.; Schlacher, T.; Udy, N.; Rissik, D.; Zeller, B.; Winning, M.; et al. Towards Understanding the Ecological Health and Character of Moreton Bay. In Proceedings of the 2nd Queensland Coastal Conference, Gold Coast, Australia, 13-15 May 2009; Gunn, J., Patmore, D., Mogg, N., Stuart, G., Hunt, S., Tindale, N., Saltner, L., Vains, J., Eds.; Queensland Coastal Conference: Brisbane, Australia, 2009; pp. 1-6.

54. Olds, A.D.; Pitt, K.A.; Maxwell, P.S.; Connolly, R.M. Synergistic effects of reserves and connectivity on ecological resilience. J. Appl. Ecol. 2012, 49, 1195-1203.

55. Watkinson, A.J.; O’Neil, J.M.; Dennison, W.C. Ecophysiology of the marine cyanobacterium, Lyngbya majuscula (Oscillatoriaceae) in Moreton Bay, Australia. Harmful Algae 2005, 4, 697-715.

56. National Land and Water Resources Audit (NLWRA). Australian Agriculture Assessment 2001; NLWRA: Canberra, Australia, 2001.

57. Capelin, M.; Koln, P.; Hoffenberg, P. Land Use, Land Cover and Land Degradation in the Catchment of Moreton Bay. In Moreton Bay and Catchment; Tibbetts, I.R., Hall, N.J., Dennison, W.C., Eds.; School of Marine Science, University of Queensland: Brisbane, Australia, 1998.

58. Neil, D.T. Moreton Bay and Its Catchment: Seascape and Landscape, Development and Degradation. In Moreton Bay and Catchment; Tibbetts, I.R., Hall, N.J., Dennison, W.C., Eds.; School of Marine Science, University of Queensland: Brisbane, Australia, 1998. 
59. Olley, J.; Wilkinson, S.; Caitcheon, G.; Reid, A. Protecting Moreton Bay: How Can We Reduce Sediment and Nutrient Loads by 50\%? In Procedings of the 9th International RiverSymposium, Brisbane, Australia, 4-7 September 2006; International RiverSymposium: Brisbane, Australia, 2006; pp. 1-9.

60. Wallbrink, P.J. Quantifying the erosion processes and land-uses which dominate fine sediment supply to Moreton Bay, Southeast Queensland, Australia. J. Environ. Radioactiv. 2004, 76, 67-80.

61. Hancock, G.; Caitcheon, G.G. Sediment Sources and Transport to the Logan-Albert River Estuary during the January 2008 Flood Event; CSIRO Water for a Healthy Country Flagship: Collingwood, Australia, 2010; p. 46.

62. Olley, J.; Burton, J.; Smolders, K.; Pantus, F.; Pietsch, T. The application of fallout radionuclides to determine the dominant erosion process in water supply catchments of subtropical South-East Queensland, Australia. Hydrol. Process. 2013, 26, 885-895.

63. Zhang, L.; Dawes, W.R.; Walker, G.R. Response of mean annual evapotranspiration to vegetation changes at catchment scale. Water Resour. Res. 2001, 37, 701-708.

64. Olley, J.; Ward, D.; Pietsch, T.; McMahon, J.; Laceby, P.; Saxton, N.; Rickard, B.; Rose, C.; Pantus, F. Phase 2a Report: Rehabilitation Priorities Knapp Creek-Final Report; Griffith University: Brisbane, Australia, 2009. Available online: http://www.healthywaterways.org/ HealthyCountry/Resources/ScienceandPlanningResources.aspx (accessed on 20 May 2013).

65. McKergow, L.A.; Weaver, D.M.; Prosser, I.P.; Grayson, R.B.; Reed, A.E.G. Before and after riparian management: Sediment and nutrient exports from a small agricultural catchment, Western Australia. J. Hydrol. 2003, 270, 253-272.

66. Holl, K.D.; Aide, T.M. When and where to actively restore ecosystems? For. Ecol. Manag. 2011, 261, 1558-1563.

67. Leigh, C.; Qu, X.; Zhang, Y.; Kong, W.; Meng, W.; Hanington, P.; Speed, R.; Gippel, C.; Bond, N.; Catford, J.; et al. Assessment of River Health in the Liao River Basin (Taizi Sub-Catchment). Brisbane, Australia; International Water Centre: Brisbane, Australia, 2012; p. 131.

68. Bunn, S.E.; Davies, P.M.; Mosisch, T.D. Ecosystem measures of river health and their response to riparian and catchment degradation. Freshw. Biol. 1999, 41, 333-345.

69. Burford, M.A.; O’Donohue, M.J. A comparison of phytoplankton community assemblages in artificially and naturally mixed subtropical water reservoirs. Freshw. Biol. 2006, 51, 973-982.

70. Nielsen, J.L.; Klausen, C.; Nielsen, P.H.; Burford, M.; Jørgensen, N.O.G. Detection of activity among uncultured Actinobacteria in a drinking water reservoir. FEMS Microbiol. Ecol. 2006, 55, 432-438.

71. Cools, J.; Broekx, S.; Vandenberghe, V.; Sels, H.; Meynaerts, E.; Vercaemst, P.; Seuntjens, P.; van Hulle, S.; Wustenberghs, H.; Bauwens, W.; et al. Coupling a hydrological water quality model and an economic optimization model to set up a cost-effective emission reduction scenario for nitrogen. Environ. Model. Softw. 2011, 26, 44-51.

72. Humborg, C.; Andersen, H.; Mörth, C.; Stålnacke, P.; Hasler, B.; Zylicz, T.; Wulff, F. RECOCA Final Report: Reduction of Baltic Sea Nutrient Inputs and Cost Allocation within the Baltic Sea Catchment 2012. Available online: http://www.bonusportal.org/files/1603/RECOCA_Final_ Report.pdf (accessed on 12 March 2013). 
73. Rolfe, J.; Donaghy, P.; Alam, K.; O’Dea, G.; Miles, R. Considering the Economic and Social Impacts of Protecting Environmental Values in Specific Moreton Bay/SEQ, Mary River Basin/Great Sandy Strait Region and Douglas Shire Waters; Institute for Sustainable Regional Development, Central Queensland University: Rockhampton, Australia, 2005.

74. Alam, K.; Rolfe, J.; Donaghy, P. Assessing the cost-effectiveness of water quality interventions in South-East Queensland. Aus. J. Environ. Manag. 2008, 15, 30-40.

75. Binney, J. Managing What Matters: The Cost of Environmental Decline in SEQ; Marsden Jacob Associates: Brisbane, Australia, 2010; p. 78.

76. Binney, J.; James, D. Sharing the Load: A Collaborative Approach to Investing in South East Queensland's Waterways; Final Report; MainStream: Brisbane, Australia, 2011; p. 55.

77. Hall, M. The Cost of Pollution: Supporting Cost-Effective Options Evaluation and Pollution Reduction; Technical Report No. 61; Urban Water Security Research Alliance: Brisbane, Australia, 2012; p. 99.

78. Hall, M. Extended Cost-Effectiveness of Water Supply Options: Case Study of the Total Water Cycle Management Plan for Moreton Bay Regional Council; Technical Report No. 88; Urban Water Security Research Alliance: Brisbane, Australia, 2012; p. 54.

79. Hermoso, V.; Pantus, F.; Olley, J.O.N.; Linke, S.; Mugodo, J.; Lea, P. Systematic planning for river rehabilitation: Integrating multiple ecological and economic objectives in complex decisions. Freshw. Biol. 2012, 57, 1-9.

80. Pagiola, S. Payments for Environmental Services: An Introduction; Environment Department, World Bank: Washington, DC, USA, 2006; p. 15.

81. Farley, J.; Costanza, R. Payments for ecosystem services: From local to global. Ecol. Econ. 2010, 69, 2060-2068.

(C) 2013 by the authors; licensee MDPI, Basel, Switzerland. This article is an open access article distributed under the terms and conditions of the Creative Commons Attribution license (http://creativecommons.org/licenses/by/3.0/). 